\title{
Endoscopic ultrasound-guided hepaticogastrostomy combined with gastroenterostomy in a case of complete duodenal obstruction
}

We report a successful case of hepaticogastrostomy combined with gastroenterostomy guided by endoscopic ultrasound (EUS) in a patient with unresectable carcinoma of the pancreatic head.

A 70-year-old woman presented with jaundice and vomiting for 3 weeks because of carcinoma of the pancreatic head. Attempts to implant a conventional intraluminal stent had failed three times owing to duodenal complete obstruction (twice at the previous hospital and once at our hospital). Therefore, we attempted EUS-guided hepaticogastrostomy and gastroenterostomy.

Because of poor function of the liver and disordered coagulation, we firstly performed hepaticogastrostomy as follows: (1) the intrahepatic bile duct (B3) was punctured with a 19-gauge needle; (2) a 0.035 -inch guidewire was inserted; (3) the path was dilated with a 6-Fr cystotome; (4) a fully covered metal stent was implanted ( Video 1, part 1); and (5) a gastric tube was placed for external bile drainage. After 5 days, we performed a gastroenterostomy as follows: (1) following puncture, a 0.035 -inch guidewire was inserted into jejunum; (2) enough saline was injected to display the proximal jejunum; and (3) a double-flanged fully covered metal stent with a cautery tip was implanted ( $\triangleright$ Video 1 , part 2 ).

The stents functioned well until the patient developed vomiting in the third month after the operation. A computed tomography (CT) scan showed that the flange of the stent in the stomach had migrated. We implanted a new stent successfully, but the patient died owing to cerebral infarction a few days later.

To the best of our knowledge, this is the first report of hepaticogastrostomy combined with gastroenterostomy in a case of

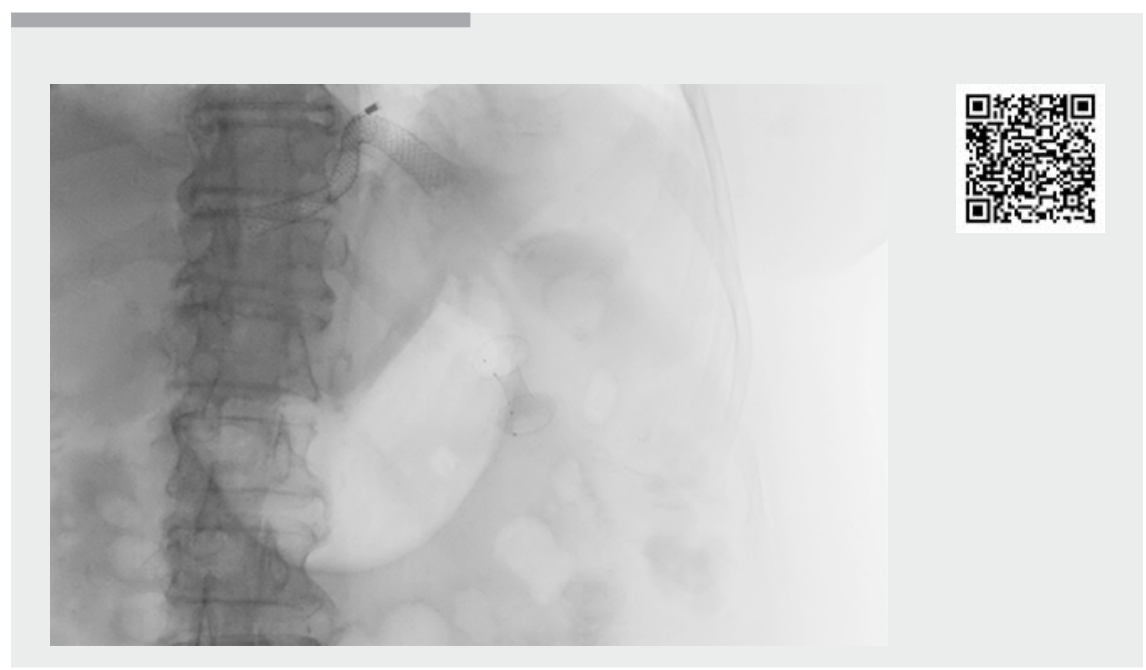

Video 1 Endoscopic ultrasound-guided hepaticogastrostomy combined with gastroenterostomy for complete duodenal obstruction.

complete duodenal obstruction. Compared with previous reports $[1,2]$, the completely obstructed duodenum in the present case significantly increased the difficulty of the gastroenterostomy procedure, as it prevented the use of a balloon catheter or ultrafine gastroscope. Hepaticogastrostomy combined with gastroenterostomy produced a satisfactory effect, but the migration of the fully covered stent should be noted and any necessary intervention should be performed promptly [3-5].

Endoscopy_UCTN_Code_TTT_1AS_2AG

\section{Competing interests}

The authors declare that they have no conflict of interest.
The authors

Shupeng Wang, Jintao Guo, Nan Ge, Sheng Wang, Wen Liu, Siyu Sun

Department of Gastroenterology, Shengjing Hospital of China Medical University, Shenyang, China

Corresponding author

Siyu Sun, MD

Department of Gastroenterology, Shengjing Hospital of China Medical University, No. 36, Sanhao Street, Shenyang, Liaoning Province, 110004, China

Fax: +86-24-23892617

sunsy@sj-hospital.org 


\section{References}

[1] Iqbal U, Khara HS, Hu Y et al. EUS-guided gastroenterostomy for the management of gastric outlet obstruction: A systematic review and meta-analysis. Endosc Ultrasound 2020; 9: 16-23

[2] Mahler MA, Prieto RG, Oria I et al. Singlesession EUS-guided hepaticogastrostomy and dual-scope gastroenterostomy: a modified technique for palliative double endoscopic biliary and gastric bypass. Endoscopy 2018; 50: 78-79

[3] Giovannini M. EUS-guided hepaticogastrostomy. Endosc Ultrasound 2019; 8: S35S39

[4] Fujisawa T, Saito H, Isayama H. Endoscopic removal of a metal stent that migrated into the peritoneal cavity after endoscopic ultrasound-guided hepaticogastrostomy. Dig Endosc 2019; 31: e74-e75

[5] Siddiqui UD, Levy M]. EUS-guided transluminal interventions. Gastroenterology 2018;

154: 1911-1924

\section{Bibliography}

Endoscopy 2021; 53: E196-E197

DOI 10.1055/a-1226-6301

ISSN 0013-726X

published online 2.9.2020

(c) 2020. Thieme. All rights reserved.

Georg Thieme Verlag KG, Rüdigerstraße 14,

70469 Stuttgart, Germany
ENDOSCOPY E-VIDEOS

https:/|eref.thieme.de/e-videos

口回 Endoscopy E-Videos is a free access online section, reporting 田: on interesting cases and new techniques in gastroenterological endoscopy. All papers include a high quality video and all contributions are freely accessible online.

This section has its own submission website at

https://mc.manuscriptcentral.com/e-videos 